\title{
SPECIFICATION AND IMPROVEMENT OF THE TECHNICAL AND FUNCTIONAL QUALITY OF FOOD TRANSPORT SERVICES
}

DATA PRZESŁANIA: 23.03.2018, DATA AKCEPTACJI: 17.06.2018, JEL CODES: D22, L15, L91, R40

\begin{abstract}
Milena Bojanowska
Faculty of Economics and Transport Engineering, Maritime University of Szczecin m.bojanowska@am.szczecin.pl
\end{abstract}

\section{Nikola Baranowska}

Faculty of Economics and Transport Engineering, Maritime University of Szczecin n.baranowska@am.szczecin.pl of services quality, represented by companies specializing in food transport, and to compare the results withrecipients' expectations. Two groups were included in the empirical study based on questionnaires prepared by the authors: road transport services providers and buyers. The results show that thepro-quality actions in the analyzed segment of TSL sector should focus on timeliness as well as on quality attributes related to cargo itself, such as: guarantee of no accidental damage or loss to goods, full quantitative and qualitative compatibility, possibility of cargo tracking by clients and extended scope of commodity condition monitoring. The above aspect shave greater importance at evaluating of operators by the customers surveyed than application of technologies dedicated to selected food groups (e.g. modified/controlled atmosphere), or availability and comprehensiveness of the services offered

perishable goods, cold chain, food logistics, monitoring of cargo condition, customer in TSL sector

\section{INTRODUCTION}

Taking into account both, the specificity of perishable goods transportation and the current approach to the quality throughout the customer's perspective, quality of food transport services may be characterized as a degree to which it satisfies the needs of users, being a function of technical, operational and economic characteristics related mainly to the technologies (means 
of transport, computerization), time (punctuality), subject of movement (cargo supervision), comprehensiveness (range of services), customer service model (staff professionalism and qualification, responsiveness) and cost of service. According to the service quality model proposed by Grönroos (1984), two groups of quality attributes in food transportation processes may be distinguished:

a) technical quality - including, in particular, tangible attributes, e.g.: condition of means of transport, loading technologies, methods and devices for monitoring the condition of the vehicle's hold, auxiliary equipment (stowage materials, portable cargo control equipment), computerization of the enterprise, technological innovation, etc.;

b) functional quality (quality of relation) - including attributes being a result of interaction between the service provider and recipient, e.g.: methods of communication, approach to the individual needs, response time, availability in unpredictable situations, attitude of the staff to service buyers, etc.

The recent empirical studies indicate that the most significant expectations of the TSL sector's customers are: timeliness, faultlessness and completeness of shipment (both cargo and documentation), safety of transportation units (theft prevention, no losses or damages, cargo control) and technical potential (Gajewska, 2015; Kozerska, 2010; Matijošius, Vasiliauskas, Vasilienè-Vasiliauskienè, Krasodomskis, 2016; Mrozik, Gostkowska-Dźwig, 2011). Although the price of the service is not its inherent feature and does not belong to qualitative attributes, it has a large impact on the customer's perception of the service (Meidute-Kavaliauskienè, Aranskis, Litvinenko, 2014) and is still an important criterion for selecting a carrier, influencing their competiveness (Flodén, Bärthel, Sorkina, 2017; Matijošius et al., 2016). In contrast to existing models for evaluating and improving logistics service quality (LSQ), focused on of alreadyexperienced service, Kilibarda, Zečević, Vidović (2012) proposed the measurement and improvement of the LSQ through the enhancing the stage of modelling and creating of logistics service specification. Applying this model consisting of three steps: determination of expected service, designing the offering, and assessment of user's satisfaction, enables to determine adequate attributes of services for the selected market segments.

The aim of this work is to examine the current approach to phases of specifying and improvement of transport services quality (technical and functional), represented by enterprises specializing in chilled and deep-frozen food transport and the comparison the obtained results to the expectations of recipients. An important part of this work is analysis of the tangible attributes having direct impact on result of operational processes as well as outcomes of services crucial in the physical distribution of food (i.e. timeliness, safety). All other criteria not directly affecting the quality of transportation service, such as: empathy, staff competence etc., have been intentionally omitted as they are non-specific for the carriage of food and should be treated as a desired dimension of creating LSQ, regardless of the type of services provided. 


\section{MATERIAL AND METHODS OF RESEARCH}

The own research was conducted using the survey method in April 2016. The questionnaires consisted of both open and closed questions, with selecting only one answer or amultiple choice option. The questionnaire, addressed to road transport providers was sent electronically to randomly selected companies specializing in food carriage; 18 feedback questionnaires (21\%) were obtained. The survey questions for service recipients were provided to medium-size companies dealing with the distribution and retailing of food products; 40 feedback questionnaires were received.

Most of the surveyed enterprises deal with both domestic and international transport. Transport services carried out by the participants of the study include mainly chilled goods - $94 \%$ of enterprises supply services for this type of food, while $56 \%$ of respondents handle frozen cargo. The structure of commodities transported by the surveyed operators indicates at the dominant share of unprocessed products. Transport of particular food groups is carried out by the following percentage of entities: fruit and vegetables - 50\%; meat and poultry - 38.9\%; prepared meals $-16.7 \%$; ice cream - $16.7 \%$; fish $-5.6 \%$.Among $94 \%$ of the enterprises included in the study, the physical process of food carriage does not last longer than 3 days. The means of transport most frequently used by the surveyed service providers are refrigerated semitrailers (declared by $89 \%$ of respondents) and refrigerated trucks (56\%). Isothermal bodies, ice trucks and isothermal semitrailers cooled by ice are used less often, by $11 \%, 11 \%$ and $5.5 \%$ of respondents respectively. The most commonly occurring loading units are pallets (94\%) and boxes (67\%). Half of the surveyed companies carry out transportation of unpackaged food (mainly meat). Containers are used by $28 \%$ of respondents.

Among the studied transport services providers, over a half (56\%) had implemented nonmandatory quality or safety management systems. The dominant standard is the quality management system (QMS) according to ISO 9001 (60\% of companies), followed by the food safety management system ISO 22000 (20\%) and International Food Safety Standard (20\%). The remaining $44 \%$ of enterprises operate only under non-certified systems related to the obligation to implement the HACCP principles.

Undertaking of transport orders in the surveyed group of enterprises takes place both on the basis of permanent and single contracts, including those concluded at transport exchanges. For the majority of respondents, cooperation with counterparties is both permanent and temporary $-87 \%$ of respondents carry out their services based on contracts signed for a longer period of time, and as many as $78 \%$ through one-off contracts. Transport exchange is used concurrently by $67 \%$ of the study participants. The structure of respondents in the group of service recipients, due to the frequency of using food transport services, indicates that $52.5 \%$ of customers outsource transportation more often than once a week. Another $25 \%$ of service recipients declared using these services once a week, on average, while $10 \%$ of respondents on a daily basis. Barely $10 \%$ of the customers use food transport services more than once a month. 


\section{RESULTS AND DISCUSSION}

\section{IMPORTANCE OF THE ATTRIBUTES OF FOOD TRANSPORT SERVICES AS THE BASIS FOR SPECIFYING THEIR TECHNICAL AND FUNCTIONAL QUALITY}

The experience of surveyed transport companies shows that the most important attributes of transportation services are: timely deliveries, price of services as well as cargo safety and security, which were indicated by $94 \%, 94 \%$ and $61 \%$ respondents respectively (Fig. 1). The above criteria reflect the requirements that the recipients most often laid down for the surveyed carriers. According to a half of the respondents, the customers are also interested in the comprehensiveness of services (the possibility of purchasing additional services such as packing, forming of cargo units, goods control) and in the possibility of tracking a cargo. Another desirable attribute of the transport service, according to the experience of carriers, is a possibility for the customer to establish climatic conditions during transport. The use of modern technologies has been marked by $28 \%$ of companies involved in the study as the most frequently requested by customers. In the carriers' opinion, the availability of services rendered, understood as the possibility of adjusting the date and place for loading to the individual needs of the recipients, is not an important qualitative dimension for the service buyers.

Transport providers $\quad$ Customers

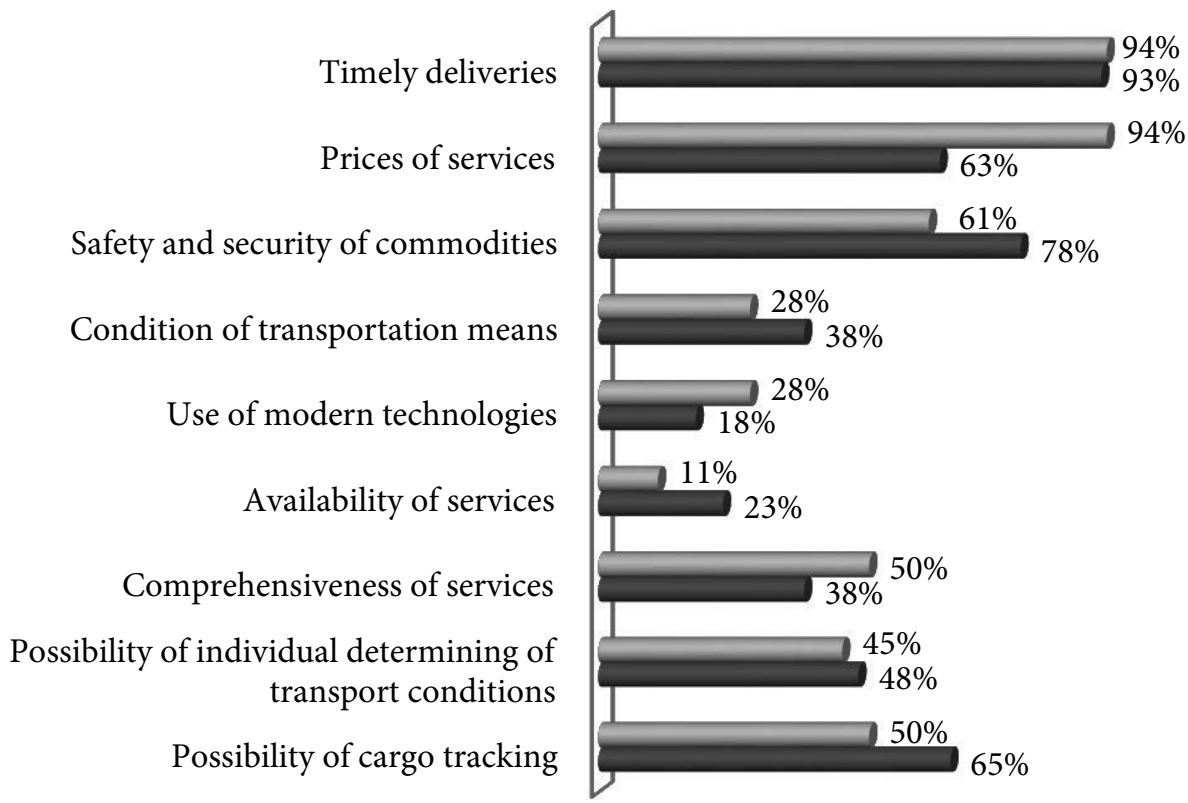

Figure 1. Significant attributes of transport services in the opinion of the providers and their customers Source: own study. 
Comparison of transport services features which, in carriers' opinions, have significant importance for customers with the results of a survey addressed to the service users (Fig. 1), in which the criteria for choosing a transport company were asked about, indicates only a partial convergence in assessing the validity of attributes, and thus means the heterogeneity between the expected service and its specification. The most significant criterion, according to the opinion of the surveyed clients, is timely deliveries (93\%) which is a feature with the highest convergence of assessments from the both contracting sides. Cargo safety and security is slightly underestimated by transport companies, important for $78 \%$ of service buyers (Fig. 1). Another attribute not fully perceived as important by services providers is the ability to track loads by the clients, indicated by $65 \%$ of customers.

The price of services, which in the carriers' opinion is equally important to the recipients as timely shipments, turned out to be less important for the studied service users - only $63 \%$ of the respondents distinguished this criterion. More significant for customers, in comparison to the assessments of carriers, are also basic attributes related to transport conditions (a possibility of individual determination of conditions, technical condition for means of transport), declared much more often than application of modern technologies.

In the opinion of $68 \%$ of service buyers involved in the study, an crucial factor determining the choice of carrier services is also a certified QMS; the most appreciated are ISO 9001 and 22000, pointed out by $57.5 \%$ and $42.4 \%$ respondents respectively.

\section{TECHNICAL AND ORGANIZATIONAL PRO-QUALITY ACTIVITIES UNDERTAKEN BY COMPANIES PROVIDING FOOD TRANSPORT SERVICES}

The shaping of the quality of services by the surveyed transport companies is associated with the scope of activities introduced by them, having the pro-quality impact (Fig. 2). Those most widespread are: improvement of condition and equipment of vehicles (78\%), implementation of IT systems (72\%) and actions increasing timely deliveries (67\%). The purchase of new means of transport is a quality improving factor, pointed out by $44 \%$ of respondents. The actions highlighted by the transport companies only partially meet the customers' essential expectations, i.e. timely shipments, safety of goods, and the ability to track the cargo. Care for technical aspects is indeed a significant factor affecting the reliability, thus safety of the cargo and timely deliveries. However, as shown further, the scope of technical improvements is, in practice of the enterprises researched, very limited and does not meet customer expectations. Moreover, transportation safety depends largely on knowledge and awareness of staff and yet only $27 \%$ and $11 \%$ of the studied carriers declare conducting qualitatively targeted trainings, for drivers and managers respectively. 
- Number of entities declaring a particular pro-quality action, in the group of 18 respondents

Trainings for management Trainings for drivers

Purchasing new means of transport Improvement of used means of transport Improvement of information flow Actions focused on timely deliveries Extending of services range Implementation of IT systems

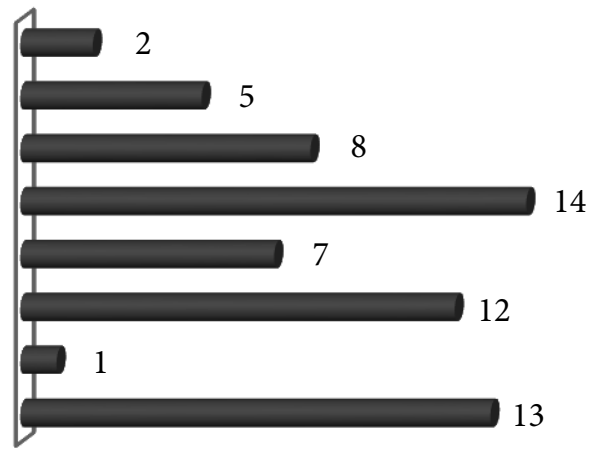

Figure 2. Activities taken by companies in order to improve the quality of transport services provided Source: own study.

The implementation of modern IT tools (e.g. electronic data exchange, portable data entry devices, vehicle monitoring systems) is now one of the competition determinants - hence, high share of surveyed enterprises taking action in this area is not surprising.

An important criterion in the assessment of customers being participants of survey is the possibility of determining individually the climatic conditions in the cargo space. Most companies (61\%) meet the above requirement, using a solution based on arrangements with the client, complying with normative and legal requirements depending on the type of food (chilled/frozen) (Fig. 3). The guidelines included in the ATP agreement are used by $39 \%$ of the surveyed companies, while recommendations from standardization documents - by $28 \%$.

- Number of entities using a particular source of information to determine the climate conditions, in the group of 18 respondents

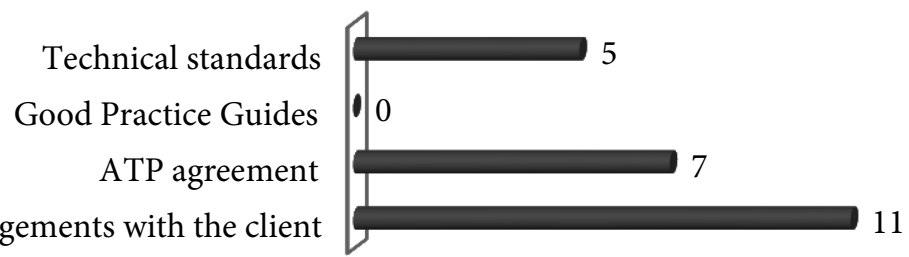

Figure 3. Sources of determining climatic conditions in the cargo space Source: own study. 
Taking into account literature data demonstrating the importance of reliability in the TSL sector, especially in relation to the subject of shipment, an extensive part of this study was an aspect of cargo safety and quality. The maintenance of product quality, as well as integrity and proper condition of the load unit is directly affected, i.a., by: the type of packaging and loading units, their proper arrangement in the cargo space, protection against mechanical, climatic and microbiological exposures, adjusted air circulation and ventilation (Bojanowska, 2007).

Number of entities pointing out a particular type of damages, in the group of 18 respondents

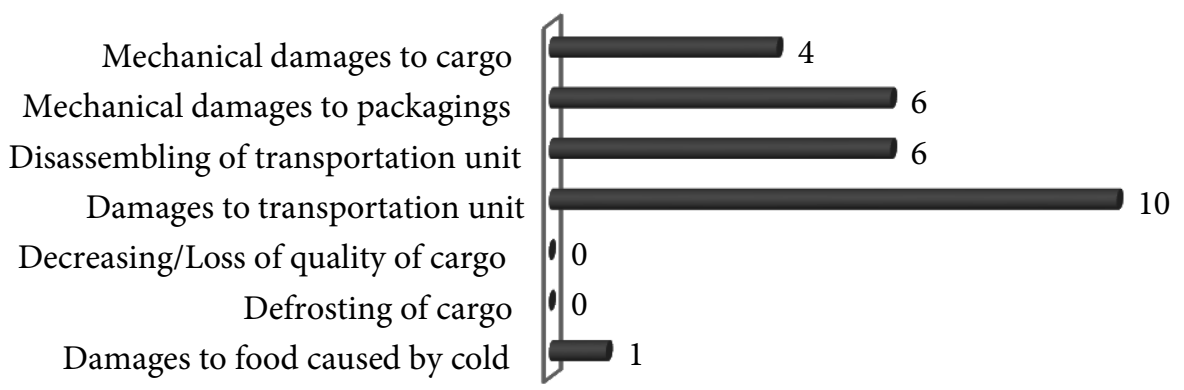

Figure 4. Types of cargo damage most often recorded among the surveyed transport companies Source: own study.

According to declaration of carriers, the frequency of incidents causing cargo quality decrease is low. Over $56 \%$ of surveyed entities experience them less often than once a year, $33 \%$ once a year and only $11 \%$ more often. None of the companies records incidents that reduce the quality or disqualify the cargo more than once a month. Among load damages occurring in practice, the mechanical ones: loading units deformations, disassembling of transportation units and damages to the individual packaging, have the greatest share (Fig. 4). Food damages during transportation are mainly of mechanical nature, as cold damages to goods are recorded only occasionally. In the group of companies surveyed, there were no cases of damages to cargoes caused by climatic or biological factors (cargo defrosting, microbiological decomposition etc.).

The approach of the surveyed companies to modern technologies supporting the technical aspect of transport is quite conservative (Fig. 5), but seems to be of secondary importance taking into account the opinion of the service buyers, with the exception of cargo tracking capabilities. The only technical solution indicated by all surveyed entities is thermography - compulsory thermometers for deep-frozen food in the cold chain. Air rotation channels or modified/controlled atmosphere dedicated to selected food groups are not used, although a half of the operators handle fruit and vegetables. The possibility of continuous tracking of cargo by the customer is guaranteed by only one carrier, which in comparison with the preferences of service users revealed in this study appears as the main aspect for improvement. 
- Number of entities declaring a particular technical solution, in the group of 18 respondents

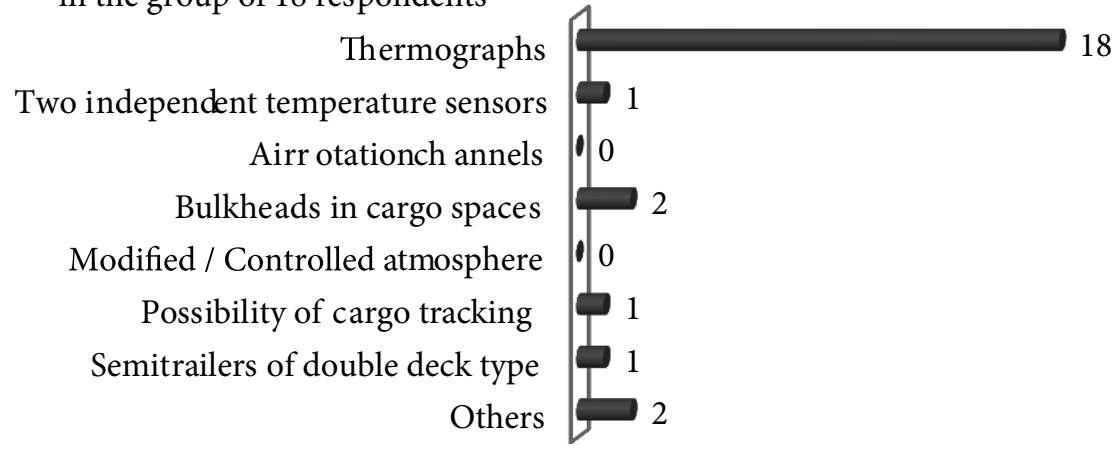

Figure 5. Technical solutions in cargo space used by the surveyed enterprises Source: own study.

\section{CUSTOMERS' EXPECTATIONS FOR IMPROVEMENT OF TECHNICAL AND FUNCTIONAL QUALITY OF FOOD TRANSPORT SERVICES}

The crucial attributes of food transport services, requiring improvement according to the service recipients, are cargo tracking technologies, service prices and the comprehensiveness of the services rendered, pointed out by $55 \%, 45 \%$ and $35 \%$ of the respondents respectively. This survey confirms that, due to the customers' expectations and the current state declared by carriers involved in study, load monitoring technologies are a weakest point of service specification. Although relatively few recipients pointed out the "comprehensiveness" as a key criterion when choosing a carrier (38\%), the comparable number of responses regarding improvement areas (35\%) puts this feature as the third (after the price of services) in the hierarchy of features for improvement. Timely deliveries and condition of vehicles, considered by the respondents as more significant, do not require enhancement in the users' opinion.

The expectations regarding cargo tracking technologies (relatively new, comparing the results presented by other authors in the last decade) arise from the growing requirements concerning information flow and the completeness of deliveries, which has been demonstrated in other authors' studies on quality in the TSL sector (Gajewska, 2015; Kozerska, 2010). Traditional supervision over the cargo during loading and stopovers (e.g. checking of load fasteners, aggregate and thermograph test, temperature measurement of compartment, packaging and commodity before loading, quality inspection of cargo) has been insufficient since cargo space monitoring systems appeared. Solutions available on the domestic market enable simultaneous monitoring of temperature and relative humidity of air in the cargo area, refrigeration unit performance and the location of a vehicle. Moreover, an additional functionality allows different parties (including the client) to log into the system. These modules can be extended with a function of monitoring of the vehicle door opening, allowing to react immediately in the case of theft attempts, as well as ensuring that the vehicle door has not been opened beyond the place of unloading. 
Number of entities indicating a particular attribute as requiring improvement, in the group of 40 respondents

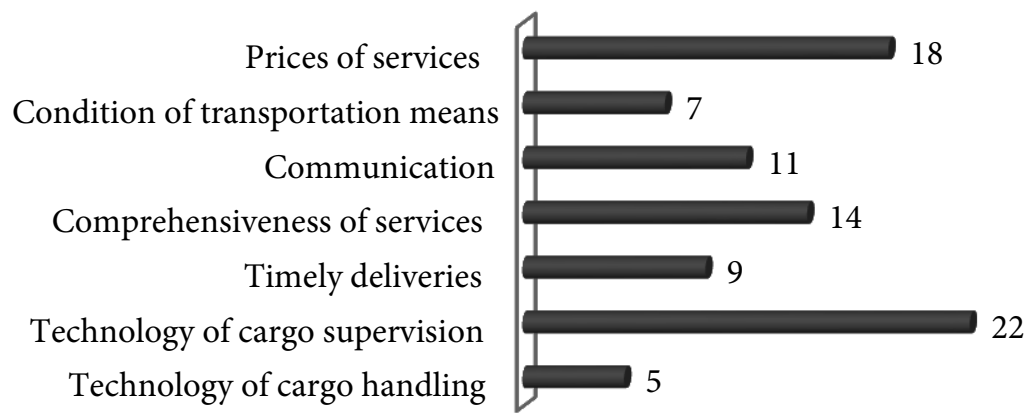

Figure 6. Quality attributes of food transport services requiring improvement in the opinion of service recipients Source: own study.

An innovative technology, which might be applied in the nearest future, isthe application of intelligent packaging for continuous monitoring of selected parameters in the product surroundings (temperature, humidity, gas composition, solar radiation, vibrations), as well as for tracking of food qualitative changes, including those caused by packaging damage or deformation (Abad et al., 2009; Vanderroost, Ragaert, Devlieghere, Meulenaer, 2014). Although the emerging technologies are immature and many difficulties still need to be overcome, it is expected that they will allow for a better monitoring of the flow, safety and quality of food products in the whole supply chain. It is estimated that the new generation sensors integrated in the circuit design of RFID tags (sensor-enabled RFID) have the greatest chance of commercial adoption in the food logistics (Vanderrost et al., 2014). Product tracking and simultaneous monitoring of the internal and external packaging environment, as well as access to the data for all parties involved requires the engagement of the both: logistics services providers and food manufacturers.

According to Nagurney, Saberi, Shukla, Floden (2015), the TSL services providers offer flexibility to meet customer expectations regarding safety and traceability, differentiating themselves from the rest of the competition, but shifting towards being more value-oriented than cost focused.

\section{CONCLUSION}

The objective of the survey was an empirical study of the approach, represented by logistics operators specializing in food transportation, to creating and improving technical and functional quality of services, as well as evaluation of the applied solutions, taking into account the clients expectations. The findings suggest that awareness of service providers regarding the attributes essential for customers, including technical and operational aspect of transport as well as its results, is relatively high, with some exceptions. The studied carriers overestimate the importance of the price for the service buyers, and at the same time underestimate the features related to 
cargo itself (safety, completeness of shipments, full quantitative and qualitative compatibility of the cargo). The surveyed service users have the greatest need for crucial outcomes of transportation service: timeliness and safety of commodities to the full extend; are unconcerned about applied modern technologies (e.g. modified/controlled atmosphere) when choosing the operator, although they expect cargo tracking possibilities with no positive feedback so far.

The majority of the surveyed service providers do not apply modern technologies dedicated to the cold chain, developing the tangible attributes of the offered service, through: improvement of already operated vehicles or purchasing new ones, implementation of IT systems, as well as by taking pro-quality actions aimed a ton time deliveries and improving information flows.

Food transportation services are evaluated by customers primarily according to timeliness, goods safety and flexibility regarding the carriage conditions. Thus, the designing of a service offer should cover, first of all, the above requirements. Nevertheless, the price is still affecting clients' decisions and their satisfaction from the service experienced, being the fourth most important factor while selecting a potential service provider.

In the services specification provided by the operators studied, there is a lack of possibilities for cargo supervision by service buyers, which seems to be the most significant feature to be included in developing food transport services. As perishable goods transport can be supported by emerging concepts of sensing and communication technologies' integrality, the future studies focused on researching customers' willingness to pay for the above innovations are needed.

\section{REFERENCES}

Abad, E., Palacio, F., Nuin, M., González, de Zárate A., Juarros, A., Gómez, J.M., Marco, S. (2009). RFID smart tag for traceability and cold chain monitoring of foods: Demonstration in an intercontinental fresh fish logistic chain. Journal of Food Engineering, 93, 394-399. DOI: 10.1016/j.jfoodeng.2009.02.004.

Bojanowska, M. (2007). Progress in shaping fruit quality in the cold chain. Proceedings of the $9^{\text {th }}$ International Commodity Science Conference (IGWT) „Current Trends in Commodity Science”, II, 710-716.

Flodén, J., Bärthel, F., Sorkina, E. (2017). Transport buyers choice of transport service - A literature review of empirical results. Research in Transportation Business \& Management, 23, 35-45. DOI: 10.1016/j.rtbm.2017.02.001.

Gajewska, T. (2015). Wyznaczenie kryteriów jakości usług logistycznych w zakresie transportu chłodniczego. Kraków: Wyd. Politechniki Krakowskiej.

Grönroos, Ch. (1984). A Service Quality Model and Its Marketing Implications. European Journal of Marketing, 18 (4), 36-44. DOI: 10.1108/EUM0000000004784.

Kilibarda, M., Zečević, S., Vidović, M. (2012). Measuring the quality of logistic service as an element of the logistics provider offering. Total Quality Management \& Business Excellence, 23 (11-12), 1345-1361. DOI: 10.1080/14783363.2012.704279.

Kozerska, M. (2010). Pomiar poziomu zgodności percepcji operatorów logistycznych i ich klientów za pomocą metody Servqual. Logistyka, 2, 162-170.

Matijošius, J., Vasiliauskas, A.V., Vasilienè-Vasiliauskienè, V., Krasodomskis, Ž. (2016). The Assessment of Importance of the Factors that Predetermine the Quality of a Service of Transportation by Road Vehicles. Procedia Engineering, 134, 422-429. DOI: 10.1016/j.proeng.2016.01.034.

Meidutè-Kavaliauskienè, I., Aranskis, A., Litvinenko, M. (2014). Consumer satisfaction with the quality of logistics services. Procedia - Social and Behavioral Sciences, 110, 330-340. DOI: 10.1016/j.sbspro.2013.12.877.

Mrozik, M., Gostkowska-Dźwig, S. (2011). Istotne czynniki wpływające na jakość usług w przedsiębiorstwie transportowym w ocenie klientów. Zeszyty Naukowe Uniwersytetu Szczecińskiego, 686, Finanse, Rynki Finansowe, Ubezpieczenia, 47, 145-154. 
Nagurney, A., Saberi, S., Shukla, S., Floden, J. (2015). Supply chain network competition in price and quality with multiple manufacturers and freight service providers. Transportation Research Part E: Logistics and Transportation Review, 77, 248-267. DOI: 10.1016/j.tre.2015.03.001.

Vanderroost, M., Ragaert, P. Devlieghere, F., Meulenaer, B. (2014). Intelligent food packaging: The next generation. Trends in Food Science \& Technology, 39, 47-62. DOI: 10.1016/j.tifs.2014.06.009.

\section{Specyfikowanie i doskonalenie jakości technicznej oraz funkcjonalnej usług transportowych żywności} towanego przez przedsiębiorstwa specjalizujące się w transporcie żywności oraz porównanie wyników do oczekiwań odbiorców. Empirycznym badaniem opartym na przygotowanym przez autorów kwestionariuszu ankietowym objęto dwie grupy: usługodawców oraz usługobiorców transportu drogowego. Wyniki wskazują, iż działania projakościowe w analizowanym segmencie sektora TSL powinny koncentrować się na terminowości dostaw, jak również na atrybutach jakości związanych z samym ładunkiem, takich jak: gwarancja uniknięcia przypadkowych uszkodzeń lub utraty towaru, pełna zgodność ilościowa i jakościowa, możliwość śledzenia ładunków przez klientów oraz monitorowanie stanu towarów w szerszym zakresie. Powyższe aspekty mają większe znaczenie przy ocenie operatorów przez klientów niż zastosowanie technologii dedykowanych wybranym grupom żywności (np. modyfikowana/kontrolowana atmosfera) czy też dostępność oraz kompleksowość oferowanych usług. towary szybko psujące się, łańcuch chłodniczy, logistyka żywności, monitorowanie stanu ładunku,
klient sektora TSL 